\section{Antibacterial Activity of a New Ready- To-Use Calcium Silicate-Based Sealer}

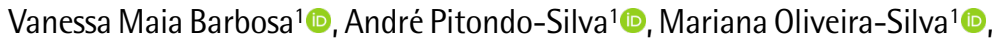
Antônio Secco Martorano ${ }^{1}{ }^{\mathbb{D}}$, Claudia de Castro Rizzi-Maia² ${ }^{\circledR}$, Yara Terezinha Corrêa Silva-Sousa ${ }^{1} \mathbb{D}$, Larissa Moreira Spinola de Castro-Raucci ${ }^{1} \mathbb{D}$, Walter Raucci Neto ${ }^{1}$ id
'UNAERP - Universidade de Ribeirão Preto, Ribeirão Preto, SP, Brazil ${ }^{2}$ Universidade CEUMA,

São Luís, MA, Brazil

Correspondence: Walter Raucci Neto, Avenida Costábile Romano, 2201, 14096-000 Ribeirão Preto, SP, Brasil. Tel: +55-16-3603-6717. e-mail: rauccineto@yahoo.com.br

\begin{abstract}
The aim of this study was to evaluate the antibacterial potential of a calcium silicatebased sealer (Bio-C Sealer, Angelus) against common bacteria in primary and secondary endodontic infections. Enterococcus faecalis, Escherichia coli, Pseudomonas aeruginosa, Staphylococcus aureus and Streptococcus mutans were exposed to fresh Bio-C Sealer for $24 \mathrm{~h}$ by the agar diffusion method $(\mathrm{n}=5)$. Additionally, the antibacterial activity was investigated against $E$. faecalis and $S$. mutans biofilms ( $48 \mathrm{~h}$ old) grown in discs with 4 $\mathrm{mm}$ in diameter and $2 \mathrm{~mm}$ in height. $(\mathrm{n}=3)$ of set discs of Bio-C Sealer (Angelus), EndoFill (Dentsply-Mallefer), Sealer 26 (Dentsply), AH Plus (Dentsply), Sealapex (Sybron-Endo) and EndoSequence BC Sealer (Brasseler). The antibacterial activity was evaluated by colony forming unity (CFU) counting using ImageJ software. Data were compared by one-way ANOVA followed by Holm-Sidak test $(\alpha=5 \%)$. Fresh Bio-C Sealer exhibited antimicrobial activity against all bacteria evaluated by agar diffusion method, except for $S$. mutans. Set discs of all endodontic sealers tested showed similar CFU values for E. faecalis ( $p>0.05$ ). $S$. mutans in biofilms showed higher susceptibility to EndoFill compared with the other sealers $(p<0.05)$. In conclusion, the results indicate that fresh Bio-C Sealer does not inhibit $S$. mutans growth, but exhibits antibacterial activity against $E$. faecalis, $S$. aureus, $P$. aeruginosa and E. coli. After setting, the Bio-C Sealer exhibits an antimicrobial potential comparable to that of the other sealers evaluated in $E$. faecalis biofilm, but lower than that of EndoFill for S. mutans biofilm.
\end{abstract}

Key Words: endodontics, calcium silicate-based sealer, antibacterial activity, biofilm.

\section{Introduction}

Studies comparing the composition and properties of endodontic sealers are relevant both to produce new materials with advantageous properties, as well as for the evaluation and improvement of those already produced today (1-3). Several types of sealers with different compositions are currently available, including those based on zinc oxide and eugenol, calcium hydroxide, epoxy resin, methacrylate resin sealers and calcium silicate-based materials $(1,3)$.

Calcium silicate-based sealers exhibit excellent biocompatibility due to their compositions, which resemble biological hydroxyapatite (2). Among the currently available calcium silicate-based sealer, Bio-C Sealer is a new ready-touse non-resinous sealer, which has been shown to favor the expression of osteoblastic markers and biomineralization when in contact with connective tissues in vivo $(3,4)$.

For successful treatment, it is known that the microbial population present in both dental and dental support tissues must be eliminated so that subsequent lesions in the periapical region do not occur. However, the complete elimination of these microorganisms is not always possible, even with a significant bacterial reduction promoted by $\mathrm{NaOCl}$ or $\mathrm{CHX}$ in association with mechanical instrumentation, bacteria may still be detected in root canals of teeth with apical periodontitis. The remaining bacteria may utilize necrotic tissue remnants in untouched root canal areas, and a additional nutrient source can be develop from tissue fluids and inflammatory exudates from the periradicular tissues as a consequence of an inappropriate apical seal (5). Thus, it is important that the filling materials used for root canal sealing have antimicrobial activity to prevent infection recurrence, also adding better healing to the affected structures (6).

Complex bacterial communities can be observed at primary and secondary apical periodontics, such as Enterococcus, Staphylococcus and Streptococcus. In fact, the endodontic treatment failures are closely related to Gram-positive and Gram-negative facultative anaerobic and anaerobic bacteria persistence inside the root canal system and periapical tissues (7). Most of the endodontic sealers usually exhibit some discrete antibacterial effects, but only before setting (5). Thus, this study aimed at evaluating the antibacterial potential of the calcium silicate-based sealers (Bio-C Sealer and EndoSequence BC Sealer) compared with sealers based on zinc oxide and eugenol (EndoFill), epoxy resin (AH Plus), epoxy resin with calcium hydroxide (Sealer 26), and methacrylate resin with 
calcium hydroxide sealer (Sealapex) on common bacteria in endodontic infections.

\section{Material and Methods Sealers}

In this study, six endodontic sealers were used: Bio-C Sealer (Angelus, Paraná, Brazil), EndoFill (Dentsply-Mallefer, Rio de Janeiro, RJ, Brazil), Sealer 26 (Dentsply Ind. and Com. Ltda, Rio de Janeiro, Brazil), AH Plus (Dentsply, DeTrey GmbH, Konstanz, Germany), Sealapex (Sybron-Endo, Orange, CA, USA) and EndoSequence BC Sealer (Brasseler, GA, USA). Sealer compositions are shown in Table 1 . The sealers were mixed and manipulated depending on the manufacturer's instructions under sterile conditions. For biofilm evaluation, discs with $4 \mathrm{~mm}$ in diameter and $2 \mathrm{~mm}$ height [adapted from Delben et al. (8)] of all sealers were forged in a silicon mold and let to set at $37^{\circ} \mathrm{C}$ in a humidified atmosphere. The discs were detached before exposition to the microorganisms.

\section{Bacterial Strains}

For the present study, five different reference bacterial strains were used: E. faecalis ATCC 4083, E. coli ATCC 25922, P. aeruginosa ATCC 27853, E. faecalis ATCC 25923 and S. $\Xi$ mutans ATCC 25175.

\section{Agar Well Diffusion Test}

Bacterial isolates of all strains were removed from stock $\left(-80^{\circ} \mathrm{C}\right)$, thawed and cultured on solid Müller Hinton $(\mathrm{MH})$ agar (Oxoid Basingstoke, Hampshire, England) at $37{ }^{\circ} \mathrm{C}$ for $48 \mathrm{~h}$. Then, three to four colonies were picked up and resuspended in $5 \mathrm{~mL}$ Luria-Bertani broth (LBb) (Oxoid) and the inoculum was adjusted to match the turbidity equivalent to $0.5 \mathrm{McF}$ arland Standard (approximately $1.5 \times 10^{8} \mathrm{CFU} /$ $\mathrm{mL}$ ) previously to antibacterial evaluation. Muller-Hinton agar plates were prepared, sterilized and inoculated (three plates for each strain) with the $0.5 \mathrm{~mL}$ McFarland scale of microbial suspensions to agar well diffusion test (9). Wells of $3 \mathrm{~mm}$ depth and $5 \mathrm{~mm}$ diameter were aseptically punched from each plate with a sterile $200 \mu \mathrm{L}$ tip base. Bio-C Sealer was placed into the wells $(n=5)$. Subsequently, the plates were aerobically incubated at $37^{\circ} \mathrm{C}$ for $24 \mathrm{~h}$, except for $S$. mutans, which was incubated in microaerophilia $\left(5 \% \mathrm{CO}_{2}\right)$. Thereafter, the diameter of the inhibition zones around each well was measured with an electronic digital caliper (Digimess, São Paulo, Brazil). The mean diameter of measured zone was analyzed to assess antimicrobial activity of fresh Bio-C Sealer.

\section{Biofilm Formation}

For biofilm formation analysis, only E. faecalis and $S$. mutans reference bacterial strains were used. The biofilm formation experiments in the sealers were carried out based on Delben et al. (8) with adaptations. After bacterial reactivation in test tubes containing $10 \mathrm{~mL}$ of Brain Heart Infusion (BHI) medium and incubation at $37{ }^{\circ} \mathrm{C}$ for $18 \mathrm{~h}$ under aerobiosis (E. faecalis) or microaerophilia (S. mutans), the strains were subcultured in solid Mueller-Hinton Agar (Oxoid), under the same conditions described above. The discs of each sealer $(n=3)$ were placed individually in 2 $\mathrm{mL}$ polystyrene cryotubes (Corning, São Paulo, SP, Brazil) containing $500 \mu \mathrm{L}$ of inoculum equivalent to McFarland scale $1\left(3 \times 10^{8}\right.$ bacterial cells per $\left.\mathrm{mL}\right)$ and $500 \mu \mathrm{L} \mathrm{BHI}$, resulting in the final inoculum equivalent to the 0.5 McFarland scale $\left(1.5 \times 10^{8}\right.$ bacterial cells per $\left.\mathrm{mL}\right)$. The discs were incubated under culture conditions and the bacterial inoculum was replaced after $24 \mathrm{~h}$ to guarantee the viability of the bacterial cells in the formation of the biofilm. Before renewing the inoculum, the discs were washed with $1 \mathrm{~mL}$ of Phosphate Buffered Saline (PBS) to remove planktonic bacterial cells not adhered to the sealers. After $48 \mathrm{~h}$ of

Table 1. Sealers compositions according to the manufacturer

\begin{tabular}{|c|c|c|}
\hline Sealer & Composition & Lot number \\
\hline EndoFill & $\begin{array}{c}\text { Powder: zinc oxide, staybelite resin, bismuth subcarbonate, barium sulphate, sodium and borate anhydrate } \\
\text { Liquid: eugenol, almond oil and BHT. }\end{array}$ & $349188 \mathrm{~K}$ \\
\hline Sealer 26 & $\begin{array}{l}\text { Powder: calcium hydroxyde, bismuth oxide, methenamine and titanium dioxide. } \\
\text { Resin: epoxy. }\end{array}$ & 338639J \\
\hline AH Plus & $\begin{array}{l}\text { Paste A: bisphenol-a epoxy resin; bisphenol-f epoxy resin; calcium } \\
\text { tungstate; zirconium oxide; silica and iron oxide. } \\
\text { Paste B: adamantine amine; N, N'-dibenzyl-5-oxanonane diamine-1,9; TCD - } \\
\text { diamine; calcium tungstate; zirconium oxide; silica and desilicone oil. }\end{array}$ & $350598 \mathrm{~K}$ \\
\hline Sealapex & $\begin{array}{c}\text { Catalyst: isobutyl salicylate resin, pyrogenic silicic acid (silicon } \\
\text { dioxide), bismuth trioxide, titanium dioxide pigment. } \\
\text { Base: n-Ethyl toluene sulfonamide resin, pyrogenic silicic acid (silicon dioxide), zinc oxide, calcium oxide. }\end{array}$ & 6738798 \\
\hline Bio-C Sealer & $\begin{array}{l}\text { Tricalcium silicate, dicalcium silicate, tricalcium aluminate, calcium oxide, } \\
\text { zirconia oxide, silicon oxide, polyethylene glycol iron oxide. }\end{array}$ & 101526 \\
\hline $\begin{array}{l}\text { EndoSequence } \\
\text { BC Sealer }\end{array}$ & $\begin{array}{l}\text { Zirconium oxide, calcium silicates, calcium phosphate monobasic, } \\
\text { calcium hydroxide, filler and thickening agents. }\end{array}$ & 10/19003SP \\
\hline
\end{tabular}


incubation, the bacterial inoculum was removed and the discs were washed with $1 \mathrm{~mL}$ of PBS.

Then, the discs were transferred to new $2 \mathrm{~mL}$ tubes containing $1 \mathrm{~mL}$ of PBS, shaken in a vortex mixer (Gehaka, São Paulo, SP, Brazil) for 30 s at maximum speed and, subsequently, for $8 \mathrm{~min}$ in an ultrasonic vibrationer (Kondortech, São Paulo, Brazil) to detach the biofilms. The quantification of biofilms was done by the CFU quantification. For this, $100 \mu \mathrm{L}$ of the collected biofilm suspension were transferred to a $2 \mathrm{~mL}$ tube containing $900 \mu \mathrm{L}$ of PBS, followed by six decimal dilutions $\left(10^{-1}, 10^{-2}, 10^{-3}, 10^{-4}, 10^{-5}\right.$ and $\left.10^{-6}\right)$. Aliquots of $100 \mu \mathrm{L}$ were inoculated according to the spread plate technique (9), with the aid of a Drigalski loop on Mueller-Hinton Agar (Oxoid), for later total CFU counting. The plates containing the inoculum were incubated for $24 \mathrm{~h}$ at $37{ }^{\circ} \mathrm{C}$ under the conditions described above. The CFU experiments were carried out in triplicate $(n=3)$ to ensure the reliability of the results obtained and allow statistical analysis. The counting of the CFU's was performed by a single calibrated and trained operator using the ImageJ software (Fiji, Bethesda, MA, USA), counting the total CFU's referring to plate number four of the serial dilution sequence (11). Data were expressed as $\log 10$ (CFU/mL).

\section{Statistical Analysis}

The experiments were done in triplicate and the quantitative data was submitted to normality and variance homogeneity tests. Data were compared using one-way ANOVA, followed by Holm-Sidak post hoc test, when appropriate. The level of significance adopted was $5 \%$.

\section{Results}

The results of the agar diffusion test revealed that fresh Bio-C Sealer promoted inhibition zone in cultures

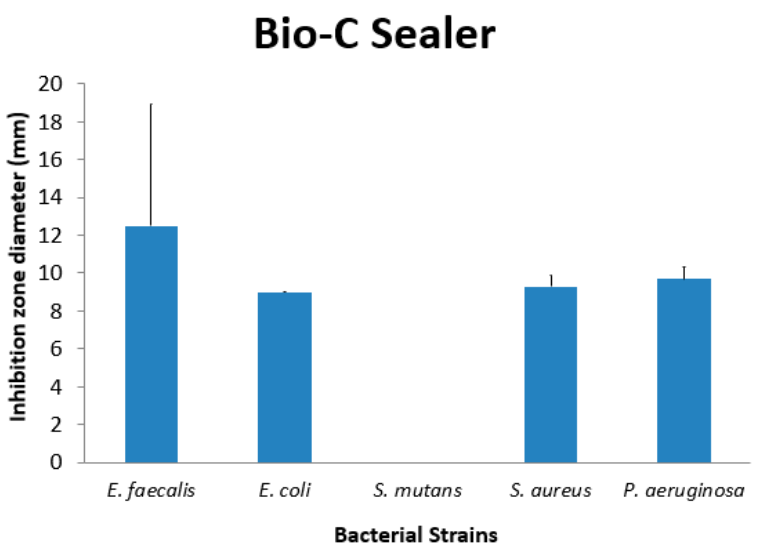

Figure 1. Mean values \pm standard deviation of diameter of inhibition zone formed in cultures of different bacterial strains exposed to fresh Bio-C Sealer. of E. faecalis, E. coli, P. aeruginosa and $S$. aureus, but not in S. mutans. Mean values and standard deviations of the inhibition zone diameters promoted by this sealer in the different bacterial cultures are shown in Figure 1.

The set discs of all sealers tested exhibited the presence of biofilm adhered onto the surface, for both tested bacterial strains. After exposure to E. faecalis biofilms, all sealers showed similar values of CFU ( $p>0.05)$, while $S$. mutans biofilms showed higher susceptibility to EndoFill compared with the other sealers, with lower CFU values $(p<0.05) . \log 10(\mathrm{CFU} / \mathrm{mL})$ values are shown in Figure 2, and the outcome of the One-Way ANOVA with Holm-Sidak post hoc test $(\alpha=5 \%)$ are displayed in Table 2.

Table 2. Mean values \pm standard deviation of $\log 10(\mathrm{CFU} / \mathrm{mL})$ of Enterococcus faecalis and Streptococcus biofilms grown in different endodontic sealers

\begin{tabular}{lcc}
\hline Sealer & E. faecalis & S. mutans \\
\hline EndoFill & $8.61 \pm 0.48 \mathrm{a}$ & $5.92 \pm 0.20 \mathrm{a}$ \\
Sealer 26 & $8.95 \pm 0.63 \mathrm{a}$ & $7.36 \pm 0.73 \mathrm{~b}$ \\
AH Plus & $9.16 \pm 0.72 \mathrm{a}$ & $7.24 \pm 0.73 \mathrm{~b}$ \\
Sealapex & $8.75 \pm 0.45 \mathrm{a}$ & $6.82 \pm 0.76 \mathrm{~b}$ \\
Bio-C Sealer & $8.65 \pm 0.61 \mathrm{a}$ & $7.55 \pm 0.58 \mathrm{~b}$ \\
EndoSequence BC Sealer & $8.82 \pm 0.56 \mathrm{a}$ & $7.40 \pm 0.74 \mathrm{~b}$ \\
\hline
\end{tabular}

Distinct letters in the same column indicate statistically significant difference among the groups (ANOVA, $\mathrm{p}<0.05$ ).
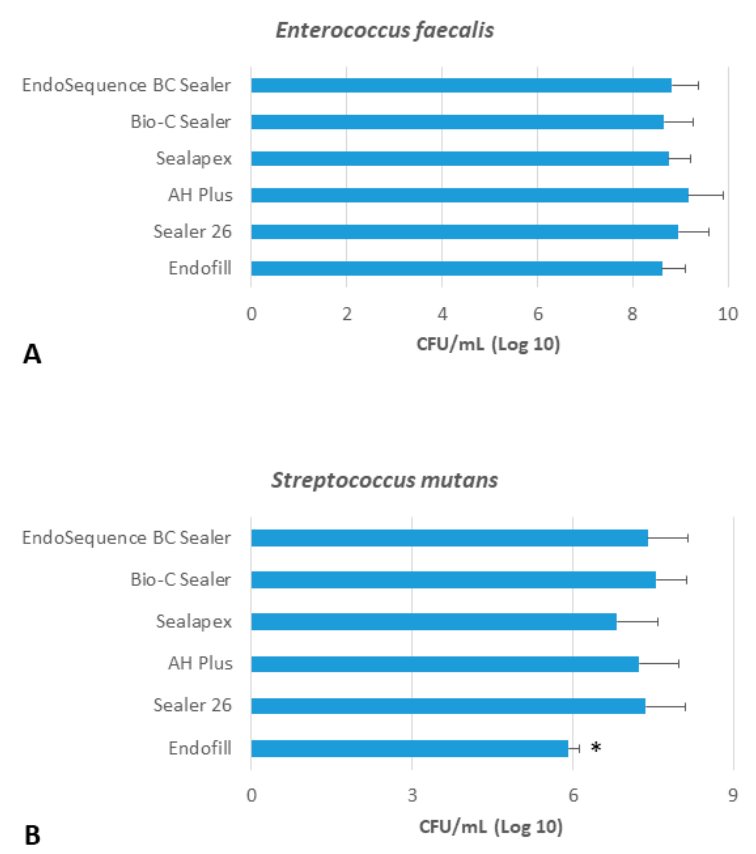

Figure 2. The in vitro antibacterial activity of six endodontic sealers against 48h-old E. faecalis (A) and S. mutans (B) biofilms. Data expressed as mean and standard deviations $\log 10$ (CFU/mL). Asterisk indicates statistically significant difference (ANOVA, $p<0.05$ ). 


\section{Discussion}

Successful endodontic treatment primarily requires effective elimination of the persistent microbial population in the apical and periapical region of a dental element (7). This occurs through mechanical debridement associated with irrigation compounds (12). In addition, the antimicrobial effect of endodontic sealers contributes to achieve this result $(2,6)$. In the present study, the antimicrobial activity of the Bio-C Sealer on common bacteria in endodontic infections was evaluated and compared with some commercially available sealers. The results showed that contact with fresh Bio-C Sealer inhibits the growth of pathogens related to the development of persistent endodontic infections, including E. faecalis, E. coli, P. aeruginosa and S. aureus, although it has no effect on S. mutans cultures. Comparing the antimicrobial potential against $48 \mathrm{~h}$-old biofilms, post-setting discs of the Bio-C Sealer exhibited behavior similar to that of the main endodontic sealers commercially available in $E$. faecalis biofilms, and less antimicrobial potential than EndoFill in S. mutans biofilms.

Antimicrobial susceptibility testing is a key factor for the prediction of therapeutic outcome. A variety of capacity. However, there are some limitations to this test, since the bacterial growth inhibition does not mean the bacterial death, this method cannot distinguish bactericidal and bacteriostatic effects, and the results should be interpreted with caution (9). For this evaluation, bacterial strains commonly isolated from primary and secondary endodontic infections were selected. E. faecalis is among the main causes of endodontic failure. It is an opportunistic bacterium with great potential for resistance to chemical compounds used for root canal disinfection, in addition to their ability to produce biofilm, invading periapical tissues, and inhibit the defense action of lymphocytes, promoting a higher degree of pathogenicity (13). In addition to $E$. faecalis demonstrating resistance to drugs used during intracanal treatment, it is also known to resist the antibacterial alkaline effect of calcium hydroxide used in intracanal dressings (14). E. coli, is a facultative anaerobic Gram-negative bacillus also isolated from periapical infections of endodontic treatments (15). E. faecalisis one of the most resistant and frequent bacteria in primary infections and recurrence of endodontic treatments (16). S. mutans, a microorganism with strong etiological potential of caries disease and also found in infected root canals associated with apical periodontitis (17). P. aeruginosa is a facultative Gram-negative bacterium frequently found in periodontal infections and has been recovered from primary and persistent endodontic infections (18).

In the present work, fresh Bio-C exhibited antimicrobial activity against all strains except for $S$. mutans. The literature shows that in addition to ability to induce biomineralization after implantation into connective tissue (4), Bio-C Sealer has capability to alkalization reaching $\mathrm{pH}$ of 10, up to 21 days (3). It is known that $\mathrm{pH}$ higher than 9 can inactivate cell membrane enzymes of microorganisms, causing loss of biological activity or integrity of the plasma membrane. Therefore, it is necessary to maintain high $\mathrm{pH}$ levels, as several species remain stable at $\mathrm{pH} 9$ or higher (19). However, the antibacterial potential considering the high $\mathrm{pH}$ values, should be evaluated with caution. The $\mathrm{pH}$ values from Bio-C samples were observed with in vitro studies after immersion in deionized water (3), and, clinically, the samples would be in contact with body fluids, which could alter the $\mathrm{pH}$ in contact with the bacterial environment. Nevertheless, considering this sealer setting time ( $\leq 240 \mathrm{~min}$ ) and high solubility, the antibacterial effects of fresh Bio-C Sealer could also be related to the significant calcium hydroxide and cement ions release (3), capable of inactivating bacterial endotoxin (LPS) potentially limiting its destructive effects on periodontal tissues. The absence of antibacterial activity against $S$. mutans is probably related to their capacity to quickly recover from $\mathrm{pH}$ shock and resume growth (20).

According to a systematic review (21), the majority of the studies on antimicrobial effect of endodontic sealers were done on planktonic bacteria, i.e. single cell isolates floating in water. This type of evaluation does not simulate an in vivo or clinical situation because the oral cavity bacteria are presented in a biofilm form, which guarantee a protected mode of growth in a hostile environment (21). Therefore, the present study also evaluates the biofilm formed in set sealers discs to mimic the clinical conditions and gives more reliable antimicrobial evidence. For this evaluation, two bacteria species were selected: E. faecalis and $S$. mutans, considering their relationship with persistent periapical infections $(14,17)$.

The antimicrobial potential of Bio-C Sealer on $48 \mathrm{~h}$-old biofilms was compared with that of some of the most widely used endodontic sealers. EndoFill is composed of zinc oxide and eugenol (22), a traditional root sealing material with favorable physicochemical properties and low cost. Sealer 26, originated and modified from AH 26 sealer, is based on epoxy resin with calcium hydroxide and bismuth, and has high adhesion power and antibacterial effect (23). Sealapex is a calcium hydroxide-based material, so its formula depends on the release of hydroxyl ions through ionization, which consequently increases the $\mathrm{pH}$ value of the medium (24). AH Plus Sealer is an epoxy 
resin sealer currently considered the gold standard due to its excellent physical chemical properties and sealing ability (25). EndoSequence BC Sealer is a premixed calcium silicate-based endodontic sealer with an alkaline $\mathrm{pH}$, high calcium ions release and antibacterial activity (2).

In the present study, there were differences in antibacterial effects against $E$. faecalis evaluated by agar diffusion method and biofilm formation. Unlike the agar diffusion method, no antimicrobial activity was observed in the bacterial biofilms formed in the tested sealers. This could be explained either by the differences in the sealers setting or by the biofilm features. The agar diffusion method used fresh sealer and the biofilm used set discs. It has been previously reported that the antimicrobial activity can be lost as the material set, with no inhibitory effect for 2- to 7-day aged sealer discs, probably due to the reduction of antimicrobial components released from the sealer matrix $(21,25)$. Also, in the biofilm, the bacteria aggregate in hydrate polymeric matrix and sessile colonies are resistant to antimicrobial agents (21). However, it has been previously observed that the presence of a membrane between sealer and biofilm did not significantly affect the antibacterial properties of epoxy- and calcium silicatebased sealers, suggesting that the antibacterial activity is primarily mediated by released substances during setting of the material (25).

Interestingly, CFU values of S. mutans were significantly reduced in EndoFill discs, indicating lower biofilm formation onto its surface in comparison with all other sealers. Corroborating with this result, the antibacterial activity of Endofill has been previously demonstrated and related to the zinc oxide particles and eugenol diffusion through the medium (26). However, the eugenol also is responsible for the Endofill cytotoxic effects, which has potential for long-term tissue irritation (22).

In conclusion, the results of the present study demonstrated that fresh Bio-C Sealer exhibit antibacterial effects against $E$. faecalis, E. coli, P. aeruginosa and $E$. faecalis strains, but not against $S$. mutans. After setting, the antimicrobial potential of Bio-C Sealer is comparable to that of the other sealers evaluated in $48 \mathrm{~h}$-old $E$. faecalis biofilm, but lower than that of EndoFill for S. mutans biofilm. These results suggest that this material could be used for endodontic treatment of teeth with and without apical infection and particularly represents a good option to the retreatment of endodontic failures.

\section{Resumo}

0 objetivo deste estudo foi avaliar o potencial antibacteriano do novo cimento biocerâmico (Bio-C Sealer, Angelus) contra bactérias comuns em infecções endodônticas primárias e secundárias. Culturas de Enterococcus faecalis, Escherichia coli, Pseudomonas aeruginosa, Staphylococcus aureuse Streptococcus mutans foram expostos a amostras frescas do Bio-C sealer durante $24 \mathrm{~h}$ pelo método de difusão em agar $(n=5)$. A atividade antibacteriana de amostras dos cimentos Bio-C Sealer (Angelus), EndoFill (Dentsply-Mallefer), Sealer 26 (Dentsply), AH Plus (Dentsply), Sealapex (Sybron-Endo) e EndoSequence BC Sealer (Brasseler) após a presa também foi investigada em biofilmes de $48 \mathrm{~h}$ das bactérias E. faecalis e S. mutans, crescidos em discos com $4 \mathrm{~mm}$ de diâmetro e $2 \mathrm{~mm}$ de altura. A atividade antibacteriana foi avaliada por contagem das unidades formadoras de colônias (UFC) utilizando o software ImageJ. Os dados foram comparados por ANOVA a um critério seguido pelo pós-teste Holm-Sidak $(\alpha=5 \%)$. Amostras frescas do Bio-C Sealer exibiram atividade antimicrobiana contra todas as bactérias avaliadas pelo método de difusão em ágar, exceto para S. mutans. A análise da formação de biofilme mostrou que todos os cimentos endodônticos testados apresentaram valores similares de UFC para E. faecalis $(p>0,05)$, enquanto biofilmes de $S$. mutans foram mais suscetiveis ao EndoFill em comparação com os demais cimentos $(p<0,05)$. Conclui-se que o cimento Bio-C Sealer fresco exibe atividade antibacteriana para $E$. faecalis, S. aureus, $P$. aeruginosa e $E$. coli, mas não inibe o crescimento de $S$. mutans. Após a presa, o cimento Bio-C Sealer exibe potencial antimicrobiano similar ao dos demais cimentos avaliados em biofilme de E. faecalis, mas inferior ao do EndoFill para S. mutans.

\section{References}

1. Marin-Bauza GA, Silva-Sousa YT, da Cunha SA, Rached-Junior FJ, Bonetti-Filho I, Sousa-Neto MD, et al. Physicochemical properties of endodontic sealers of different bases. J Appl Oral Sci 2012;20:455-461.

2. Jitaru S, Hodisan I, Timis L, Lucian A, Bud M. The use of bioceramics in endodontics - literature review. Clujul Med 2016; 89:470-473.

3. Zordan-Bronzel CL, Esteves Torres FF, Tanomaru-Filho M, ChávezAndrade GM, Bosso-Martelo R, Guerreiro-Tanomaru JM. Evaluation of physicochemical properties of a new calcium silicate-based Sealer, Bio-C Sealer. J Endod 2019;45:1248-1252.

4. Benetti F, Queiroz ÍOA, Cosme-Silva L, Conti LC, Oliveira SHP, Cintra LTA. Cytotoxicity, Biocompatibility and Biomineralization of a New ready-for-use bioceramic repair material. Braz Dent J 2019;30:325-332

5. Siqueira Junior JF, Rôças IDN, Marceliano-Alves MF, Pérez AR, Ricucci D. Unprepared root canal surface areas: causes, clinical implications, and therapeutic strategies. Braz Oral Res 2018;32:e65.

6. Singh G, Elshamy F M, Homeida HE, Boreak N, Gupta I. An in vitro comparison of antimicrobial activity of three endodontic sealers with different composition. J Contemp Dent Pract 2016;17:553-556.

7. Siqueira-Junior JF. A etiology of root canal treatment failure: why well-treated teeth can fail. Int Endod J 2001;34:1-10.

8. Delben JA, Zago CE, Tyhovych N, Duarte S, Vergani CE. Effect of atmospheric-pressure cold plasma on pathogenic oral biofilms and in vitro reconstituted oral epithelium. PLoS One 2016;11:e0155427.

9. Balouiri M, Sadiki M, Ibnsouda SK. Methods for in vitro evaluating antimicrobial activity: A review. J Pharm Anal 2016;6:71-79.

10. Tortora, Gerard J., Funke, Berdell R.Case, Christine L. Microbiology: An Introduction. Boston: Pearson, 2013.

11. Joshi SG, Paff M, Friedman G, Fridman G, Fridman A, Brooks AD. Control of methicillin-resistant Staphylococcus aureus in planktonic form and biofilms: a biocidal efficacy study of nonthermal dielectric-barrier discharge plasma. Am. J. Inf. Control 2010;38:293-301.

12. Yoo YJ, Perinpanayagam H, Oh S, Kim AR, Han SH, Kum KY. Endodontic biofilms: contemporary and future treatment options. Restor Dent Endod 2019;44:e7.

13. Kayaoglu G, Ørstavik D. Virulence factors of Enterococcus faecalis: relationship to endodontic disease. Crit Rev Oral Biol Med 2004;15:308320.

14. Evans M, Davies Jk, Sundqvist G, Figdor D. Mechanisms involved in the resistance of Enterococcus faecalis to calcium hydroxide. Int Endod J 2002;35:221-228.

15. Gomes BPFA, Herrera DR. Etiologic role of root canal infection in apical periodontitis and its relationship with clinical symptomatology. Braz Oral Res 2018;18:e69.

16. Zan R, Kutlu G, Hubbezoglu I, Sumer Z, Tunc T, Mutlu Z. Bactericidal effects of various irrigation solutions against Staphylococcus aureus in human root canal. J Istanb Univ Fac Dent 2015;49:19-26. 
17. Gomes BP, Pinheiro ET, Gadê-Neto $C R$, Sousa EL, Ferraz CC, Zaia $A A$, et al. Microbiological examination of infected dental root canals. Oral Microbiol Immunol 2004;19:71-76.

18. Fujii $R$, Saito $Y$, Tokura $Y$, Nakagawa KI , Okuda K, Ishihara K .l. Characterization of bacteria flora in persistent apical periodontitis lesions. Oral Microbiol Immunol 2009;24:502-505.

19. Estrela C, Sydney GB, Bammann LL, Felippe Júnior O. Mechanism of action of calcium and hydroxyl ions of calcium hydroxide on tissue and bacteria. Braz Dent J 1995;6:85-90.

20. Castillo A, Rubiano S, Gutiérrez J, Hermoso A, Liébana J. Post-pH effect in oral streptococci. Clin Microbiol Infect 2000;6:142-146.

21. AlShwaimi E, Bogari D, Ajaj R, Al-Shahrani S, Almas K, Majeed A. In vitro antimicrobial effectiveness of root canal sealers against Enterococcus faecalis: A Systematic Review. J Endod 2016;42:15881597.

22. Moura CCG, Cunha TC, Crema VO, Dechichi P, Biffi JCG. A study on biocompatibility of three endodontic sealers: intensity and duration of tissue irritation. Iran Endod J 2014;9:137-143.

23. Batista RFC, Hidalgo $M$ Roberto K.N et al. Microscopic analysis of subcutaneous reactions to endodontic sealer implants in rats. J Biomed Mater Res 2006;81:171177.

24. Sampaio FC, Alencar AH, Guedes OA, Veloso HH, Santos TO, Estrela C1. Chemical elements characterization of root canal sealers using scanning electron microscopy and energy dispersive X-ray analysis. Oral Health Dent Manag 2014;13:27-34.

25. Kapralos V, Koutroulis A, Ørstavik D, Sunde PT, Rukke HV. Antibacterial activity of endodontic sealers against planktonic bacteria and bacteria in biofilms. J Endod 2018:44:149-154.

26. Marchese A, Barbieri R, Coppo E, Orhan IE, Daglia H, Nabavi SF, Izadi $H$, et al. Antimicrobial activity of eugenol and essential oils containing eugenol: A mechanistic viewpoint. Crit Rev Microbiol 2017;43:668689.

Received August 1, 2020 Accepted October 1, 2020 